\title{
Labor Unions' Role for Environmental Protection - by Exerting Efforts for Training, Education and Awareness of Workers about Environment.
}

\author{
${ }^{* 1}$ Muhammad Tariq Khan, ${ }^{2}$ Naseer Ahmed Khan, ${ }^{3}$ Tashfeen Muhammad \\ ${ }^{4}$ Hamaaduddin Khan7, ${ }^{5}$ Waleed Ahmed Khan
}

\author{
${ }^{1}$ Head Department of Management Sciences, University of Haripur, PAKISTAN \\ ${ }^{2}$ Postmaster General, Pakistan Post Rawalpindi, PAKISTAN \\ ${ }^{3}$ BS Student, Environmental Sciences, Bahria University, Islamabad, PAKISTAN \\ ${ }^{4}$ BS Student, Geo Physics, Bahria University, Islamabad, PAKISTAN \\ Author's Email: ${ }^{2}$ nakhan59@yahoo.com, ${ }^{3}$ Tashfeenkhan606@gmail.com, ${ }^{4}$ Waleedkhan69@gmail.com
}

*Corresponding Author’s Email: tariq_phd@yahoo.com

\begin{abstract}
Labor unions are the organization which by definition are only struggling to secure benefits for their members, such as financial gains like rise of wages, bonuses, various allowances like insurance benefits, overtime payment and non financial benefits such as job security, comfortable work place recreational facilities and decreasing fear of employer through collective bargaining. But Unions also have social and developmental roles. Several studies have shown that unions also have rendered services beyond collective bargaining. This study is focused to explore the role of labor unions in protection of environment through workers training and education and awareness about environment problems, which is much away from their definitional mandate.
\end{abstract}

Keywords: Labour union, Labour union role, environmental protection, development, workers training, Environmental awareness.

\section{Introduction}

According to International Labor Organization's (ILO) 'World Labor Report 1997-1998', The Australian Bureau of Statistics has defined union as: "An organization, consisting predominantly of employees, the principle activities of which include the negotiation of pay and conditions of employment for its members." Knowles and Eade (n.d.) wrote that the core business of labor unions is to organize for fair terms and conditions of work, negotiate on behalf of the work force, provide services for members, network, and mobilize them. Snell et al. (n.d) expressed that labor unions are rarely recognized for their roles and activities outside of industrial matters. When union activities surrounding non-industrial matters serve as a focal point they are often analyzed or discussed in relation to productive relations and the vested interests of trade union organizations.

Many researchers have reported that general perception about labor unions is not positive (Khan. 2010). They believe that unions are largely responsible for low productivity and lower production. Employers allege that labor unions, only talk about workers' rights and ignore their obligations (Ghayur 1996).

But according to Khan $(2008,2010$,$) Khan and Khan 2011) unions are also playing role beyond collective bargaining$ in 'Environment \& Climate Change', 'Energy Resources Planning \& Management', Public Health \& Sustainable Development', Poverty Alleviation, and Training, Education \& Skill Building and also for the benefit of employers. Therefore many researchers have admitted the unions' role beyond their definitional mandate. As Kojola (2009) reported that the United Steel Workers (USW) has a long history of environmental activism. In the 1948 "Killer Smog" incident in Donora, Pennsylvania an air pollution disaster killed 20 people, including USW members. When the government failed to investigate, the union led its own investigation and drew the attention of other unions to their efforts. Similarly Gabaglio \& Sapir (2002) opined that although European trade unions are primarily recognized as central actors within economic and social spheres, they have also been involved with environmental issues for a long time. As a result of this experience, it is becoming more and more clear that environmental issues can no longer be 
regarded as an external cause outside of a union's core domain to be dealt with as part of the trade unions' extended responsibilities. Instead, unions are recognizing that environmental questions are intrinsically connected to core trade union issues concerning resources, risks, democracy and equity. So programmatic trade unions in Europe have adapted their political programs to face the environmental challenge, and have issued statements accordingly. CSD (2008) admitted that workers and trade unions involvement are essential ingredients for change where collaboration with employers and governments could facilitate effective workplace action for environmental protection and community well being.

Because labor unions being organized bodies are capable, to exert efforts, for addressing social problems and protection of environment so this paper is dedicated to study the role of labor unions in the protection of physical environment by providing training, education and awareness to their members or environmental workers.

\section{Research Methodology}

This research article has been developed from descriptive secondary information searched by reviewing literature about role of labor unions for environment protection published in research journals in the form of research articles, working papers of institutions and universities, research reports of various organizations and books of labor unions concerned scholars and environment concerning scientists.

\section{Environmental Problem}

Leeuwen (2009) reported that at a recent UN leadership forum, Secretary General Ban Ki-moon told more than 100 international leaders that climate change is the pre-eminent geopolitical and economic issue of the 21 st century and Gabaglio \& Sapir (2002) had also expressed that the most serious problem is climate change resulting from emissions of greenhouse gases, due to use of fossil fuels used to obtain energy which is a basic resource to social and economic development. But its use and transformation have caused significant environmental problems, ranging from urban pollution to acid rain, marine pollution and nuclear waste.

Oswald \& Eldret (2009) also disclosed one more sector responsible for environmental problems, the travel and tourism industry. In 2007, the 'World Tourism Organization' estimated the number of tourists to be 898 million, globally, almost half of whom traveled by air. Air travel and transport are estimated to be responsible for between 2 and $3 \%$ of total $\mathrm{CO}_{2}$ (Carbon Dioxide) emissions. Tourist accommodation is also a major contributor, due to the use of heating and air conditioning.

Ryder's (2009) report disclosing the fact that an average 262 million people per year were affected by climate-related disasters during 2000-2004, underlines the scale of the threat. The world is beginning to run out of time; we cannot wait any longer for the worst effects of climate change to be avoided, or at least reduced. Ryder asserted that urgent action to tackle climate change is the only way for massive economic, social and environmental damage or even catastrophe to be averted.

Ryder (2009) further narrated that a Just Transition towards a low carbon economy is possible. It can make climate action a driver for sustainable economic growth and social progress, as well as a tool for improving the living and working conditions of workers. For this to happen, trade unions must have a strong voice so that the views and needs of today's, and tomorrow's, workers are heard. Trade unions seek to contribute to the transformation aspects of a broader social and economic strategy for change, in which environmental concerns are integrated into our traditional demands - workers' rights, greater equality and social justice. The global trade union movement is calling on governments to commit urgently to emission reductions. This must be done in line with the principle of 'common but differentiated responsibilities' and take account of countries' varying capacities.

Kojola, (2009) revealed that in March 2008 the American labor union, (American Federation of LaborCongress of Industrial Organizations) AFL-CIO 's Executive Council issued a statement saying, "It is time for our nation to take bold steps to meet the 21 st century challenges related to climate change. Scientific evidence has confirmed that human use of fossil fuels is undisputedly contributing to global warming, causing rising sea levels, changes in climate patterns and threats to coastal areas." The Federation now backs a cap and trade policy, along with investment incentives for clean energy. 


\section{Involvement of Unions in Environmental Affairs}

According to Canadian Labor Congress (2003) one thing is certain, that young people today are demanding that something be done to safeguard the world that they will be part of. If the labor movement wants to win the respect of the next and future generations, we must become an active participant in that struggle.

Kojola (2009) is of the opinion that unions are recognizing that environmental questions are intrinsically connected to core trade union issues concerning resources, risks, democracy and equity.

According to Inoue (1999) in Japan before Rengo (a large Japanese labor union) was established, trade unions were already active in environmental protection. They had been campaigning against water pollution, air pollution and deforestation since the 1960s. Rengo has expanded the scope of its environmental policy to include global issues since around 1992 when Rengo sent a delegation to the Global Environment Summit held in Rio de Janeiro. The pillars of Rengo's environmental policy are prevention of global warming, control over hazardous chemicals, and the promotion of waste management/ recycling. It also advocates environmental standards for industry and respect for the natural environment. Rengo's approach is to structure a recycling society, and the organization has gradually developed a way of promoting environmentally sustainable business and industry, community living and personal lifestyle.

About USA Kojola (2009) reported that, before the mass environmental movements, of the late 1960s, labor was one of the strongest supporters of pollution control because of occupational and public health concerns. In the early 20th century, unions and environmental groups began to make connections between hazardous materials in the workplace and in the environment. By the 1970's labor support in USA helped to pass 'The Clean Air Act 1970' and 'The Clean Water Act 1972'. Environmentalists for Full Employment was formed in the 1970s and organized several conferences with unions and garnered support for the 'Humphrey-Hawking full employment bill'.

Ryder (2009) has traced that trade the union discussions on sustainable development began with preparations for the world's first 'Earth Summit' in Rio de Janeiro in 1992. This process has intensified in recent years, particularly in the course of developing a common policy and strategy relating to the December 2009 meeting in Copenhagen of the United Nations Framework Convention on Climate Change (UNFCCC).

According to European Trade Union Council (ETUC, 2002) the Johannesburg Earth summit provided the platform for the development of a global action plan, in which the involvement of trade unions in the development and implementation had been assured. Buffa et al (2008) and Kojola (2009) expressed that in USA unions like the United Steel Workers (USW) rank and file has been militant on environmental issues, promoting environmental improvements, opposing compromises over air quality regulations in the 1970 s, even if it meant job loss, playing a key role in the passage of the Clean Air Act, and more recently in global warming mitigation policy.

Gabaglio \& Sapir (2002) expressed that the labor movement's stance on climate change has evolved in the past eight years, as unions are beginning to recognize the job benefits from a green economy and reconsider their stance on clean energy, the environment and climate change. Environmental issues have been raised in collective bargaining by trade unions. Topics like hazardous substances, traffic, waste handling have been put on agendas. Workers' representatives and trade unions have acquired rights to take environmental initiatives and to participate in drafting environmental management plans. Gabaglio \& Sapir further expressed that trade union members, health and safety representatives and works councils have taken initiatives to improve the standard of environmental management through training courses.

Buffa et al (2008) wrote that today U.S. unions are starting to voice their support for policies to reduce global warming. Factors leading to the shift include increasing concern about climate change amongst the general public, concern about worker health and safety, and the influence of such groups as the Apollo Alliance, which is a coalition of labor unions, environmentalists, community groups, and businesses that advocates for clean energy policies that would both address the climate crisis and expand opportunities for U.S. businesses and workers. Buffa et al quoted a statement of SEIU (Service Employees International Union) Executive Vice President Gerry Hudson: "We already know that working people are disproportionately affected by environmental degradation and the negative impacts of global warming," says "It is our duty as labor leaders to take a strong stand and carve out the role we will play in solving what may become the most critical issue of our time."

Valenduc (2000) reported that in 1995, the Belgian chemical industry 'CSC-union of 'white collar workers' (CNE) received the yearly award of the environmental associations ("green palm"), as an acknowledgement for its initiatives and actions in the area of prevention and protection of the environment.

Kojola (2009) stressed that European trade unions must develop their own perspective on sustainable development, based on their specific European trade union position vis-à-vis the urgent need for integrated social, economic and environmental approaches to meet the world's most pressing challenges. 


\section{General Role of Unions in Environmental Protection}

According to Canadian Labor Congress (2003) 'The Brotherhood of Locomotive Engineers' (BLE) has worked on lowering diesel emissions and the re-burning of exhaust; lobbied for rail fuel tax reductions; and, pressured employers over sturdier railcars.

Ryder (2009) expressed that respect for rights is also critical to sustainable development. It is important that current workers are able, through their trade unions, to participate in and influence changes, just as it is vital that workers in new jobs created by a 'greener' economy have their rights fully protected, in particular their rights to organize and bargain. Trade unions seek to contribute to the transformation aspects of a broader social and economic strategy for change, in which environmental concerns are integrated into our traditional demands workers' rights, greater equality and social justice.

Labor unions have mad many alliances for the protection of environment. Workers' labor unions have joined with green workers. In USA according to Kojola (2009) labor unions entered in Apollo Alliance. The Apollo Alliance is a blue-green partnership that started in 2003 as a coalition of unions, environmentalists and businesses around building a clean energy infrastructure and shaping the economy to create jobs while protecting the environment. The national AFL-CIO (American Federation of Labor-Congress of Industrial Organizations), and many other unions, including the BGA (Blue-Green Alliance) partners, United Mine Workers (UMW), International Brotherhood of Electrical Workers (IBEW), International Association of Machinists and Aerospace Workers (IAMAW) and 'Transportation Workers' have endorsed Apollo Alliance. Many environmental organizations have also endorsed Apollo Alliance, including the (National Resource Defense Council) NRDC, Sierra, Rainforest Action Network, Union of Concerned Scientists, Green-peace and National Wildlife Federation. Apollo has affiliate organizations and programs across the country at the state and local levels that are engaged in many different roles from lobbying and legislative work to state-level think tanks to community organizing. Unions have a less direct role in Apollo, but the board includes several union representatives who have an equal voice to business and environmental groups. Apollo provides a forum for labor, environmentalists and business to work together and find common ground, while promoting green jobs at multiple levels.

Kojola (2009) also quoted 'Progressive Movement' which is an alliance between labor unions and environmental organizations. These alliances are part of a broad strategy to build a social movement around progressive issues. Both sides have realized that they are unlikely to achieve their goals by working alone and have come to understand the inter-relation between their issues. Tony Daley, research economist with the Communications Workers of America (CWA), speaks of green jobs as becoming a venue for progressive cooperation and potentially creating a social movement to alter the direction of the economy.

Evans (2009) expressed that achieving environmentally and socially sustainable economic growth the trade union movement is urging developed countries to make ambitious commitments on emission reductions, in line with their responsibilities and their capacities. Action to meet these commitments will drive changes in production and consumption patterns, creating new jobs and transforming existing ones. Climate change action is thus one of the main building blocks of a new economic model, which takes account of the fragility of our natural resource base and the need to preserve it for future generations. But securing social sustainability in the shift to the green economy will depend, on achieving a Just Transition.

Snell et al. (n.d) demonstrated in their paper that unions in Australia have begun to open up a range of concerns and activities in relation to the environment and climate change. Unions are seeking to develop their capacities as an environmental actor through a range of activities focusing on internal solidarity (e.g. educating members about climate change and sustainability), external solidarity (e.g. campaigns in support of national and international framework agreements for reducing carbon emissions), and proactive initiatives such as those aimed at 'transitioning' local industries and economies towards a sustainable future. Coalitions with other environmental organizations are important to union capacity building around environmental matters, particularly with regards to strengthening environmental legislation campaigns.

According to WSSD (2002) in the Czech Republic, the Mine, Geology and Oil Industry Workers' Union's "Train the Trainers Program" extends awareness into the community and Russian and Norwegian unions, cooperate in the Barents Region to provide training and job experience for Russian workers, engineers and advisers in 'Cleaner Production (CP) technology', waste minimization, energy conservation, and sound ecological processes.

A report of European Trade Unions Council (ETUC, 2002) revealed that an analysis of the environmental initiatives pursued by European trade unions over the last decade is also called for in the context of Rio +10 , demonstrated the extent to which trade unions have succeeded in being a driving force in integrating the environment into social and economic development. 


\section{Labor Unions' Role in Training Education and Awareness of Workers For Environment protection}

Kojola (2009) expressed that 'training' is an especially important function for unions at the state and local level where unions can work with businesses, government and colleges to create training programs that are integrated with economic development and create pathways to green-collar jobs. Even in the face of anti-union politicians and corporations, unions can utilize their ability to train workers, which will be needed for a rapid green transition, as leverage to be involved in policy and economic development decisions. In order for unions to have an active voice in economic planning, organized labor will have to provide something that business and government want, like securing a stable and experienced workforce. So unions are actively engaged in green job creation through apprenticeship training programs that provide workforce development designed for a green economy and form linkages between skilled workers and companies. Union apprenticeship programs help to propel new members into green occupations and upgrade the skills of existing members to meet the needs of a green economy. Union training capacity is seen as one of the best ways to guarantee good wages and benefits by improving workers position in the labor market and that unions are in a good position to use federal money to expand green training. Through cooperation unions can incorporate education programs with business demands and help to secure skilled workers for new business investments; the USW (United Steel Workers) assisted Gamesa in finding a labor force for their wind turbine manufacturing plants.

Gabaglio and Sapir (2002) by quoting the example of FNV Bondgenoten (Federatie Nederlandse Vakbeweging or federation of labor unions of Netherlands) has expressed that in the Netherlands FNV Bondgenoten has started a discussion with members in the agricultural sector who deal or may deal with biotechnology. The union was also involved in reforming education for present and future workers, to ensure safe work on a good product.

In Canada according to Canadian Labor Congress (2003) 'The Ontario English Catholic Teachers Association' (OECTA) has done much to promote environmental education in schools, with waste reduction projects, ecological education and "walking school buses".

About Europe Canadian Labor Congress (2003) narrated that 'The European Trade Union Council' (ETUC) made education and training a key part of their recommendations for sustainable job creation:

"Schools, especially vocational training schools, should equip students and trainees with greater ability to adapt to technological and economic changes and with skills relevant to an environmentally-friendly labor market."

The ETUC also suggested that programs of educational leaves be granted to workers for skill development in cleaner production processes and handling of new technology (allowing for temporary workers to be employed in their places, and gaining work experience). Employees trained in sustainable practices and principles would form a skilled and motivated workforce capable of participating in workplace decision-making to improve the sustainability of the workplace and job security of workers employed there.

Canadian Labor Congress (2003) also narrated that the Swedish union TCO initiated a unique program for identifying office furniture, equipment and practices that combine environmental and occupational health concerns. The union invented the "6E" label, which is applied to equipment assessed for Ergonomics, Ecology, Emissions, Efficiency, Economy and Energy. The union negotiates with employers to buy only that equipment which meets the union standards and gets the label. In supplying union members with computers, TCO is now the biggest retailer of computers in Sweden!

Buffa et al (2008) has disclosed that some California labor unions have been leading the way in creating new training programs, campaigns, and coalitions to address climate change and green jobs in their industries and communities. In April 2008, the California Labor Federation's Executive Committee adopted a set of climate action principles. Since then, Labor Federation staff have organized educational and action plan meetings on $A B 32$ (Assembly Bill 32). The Labor Federation and State Building \& Construction Trades

Council (SBCTC) created a coordinated message and talking points for labor leaders and activists wishing to participate in the $A B 32$ process.

Buffa et al (2008) added that solar energy is one of the fastest growing areas of the new green economy in California. Southern California's 'International Brotherhood of Electrical Workers' (IBEW) union (Local 11) is a leader in training electricians in the art of installing and maintaining solar panels. Local 11 has trained 2,000 licensed electricians in California so far, and its training program used, by the IBEW International, as a model for other locals across the U.S. The courses are funded by the Los Angeles County Chapter of the 'National Electrical Contractors Association' (NECA) and IBEW Local 11 through the Southern California IBEW-NECA Labor-Management Cooperation Committee. They also received California state government training funds. In its weekend training program, Local 11 trained journey level electricians in the national electrical code relevant to solar, requirements for proper solar installation, sizing solar panel systems, and getting maximum photovoltaic output from the panels. 
White Aidan (2009) revealed that the (International Federation of Journalists) IFJ and other Global Union Federations are also working on communications programs with the wider trade union movement, much of it in countries where the impact of climate change is being felt and where there will be potentially disastrous consequences. Unions need to ensure that their messages about how they and their members are responding to the crisis are getting into the communications mainstream. Unions realize more than ever that media have both the reach and credibility to make all stakeholders take climate change issues seriously.

Oswald \& Eldret (2009) expressed that alongside social and labor issues, the travel and tourism industry faces considerable environmental challenges. So the 'International Union of Food, Agricultural, Hotel, Restaurant, Catering, Tobacco' (IUF's Hotel), Restaurant, Catering and Tourism (HRCT) Group is developing strategies to educate and mobilize trade unions in the sector to tackle climate change. In 2008, the Group agreed targeted lines of action corresponding to the right to participate and monitor and the right to information, training, and tourism.

Kojola (2009) asserted that the USW launched an initiative for member education in which fifteen members were taken off the job and trained in climate science, environmental economics and green jobs. They then recruited another 350 volunteer members to become organizers who would be trained to give talks to fellow union members, with the goal of talking to 185,000 members five times each over a three-month period. The BGA (Blue-Green Alliance) is planning a similar union member education drive that will extend to all the union affiliates.

Leeuwen (2009) revealed that 'Education International' (EI) and its affiliates insist that climate change is, indeed, a union issue. Education unions are beginning to engage in collective bargaining for measures to reduce the carbon footprint of their schools, colleges and universities. Some member organizations are already recruiting environmental reps, which would work like green shop stewards to promote environmentally positive policies and practices. Change is never easy. But in these times of multiple global crises it's more important than ever that we work in a spirit of collective good will and solidarity to build a new global agreement to mitigate climate change. EI proposed following practical steps for union action on climate change

1. Mobilize: Encourage colleagues and others to take part in meetings, leaders to put climate change high on the agenda, and then put your message out on the streets and across the airwaves.

2. Negotiate: Work to have environmental representatives recognized with the same status and statutory rights as shop stewards or health and safety reps. Negotiate with management about energy savings in your workplace.

3. Teach: Educate your children, students, apprentices, colleagues, friends, family and others about the importance of global citizenship and democratic involvement. Help to build a new generation that can make sense of the climate science. Climate scientists should assert greater control over the research agenda.

European Foundation (2011) mentioned that in Romania, a joint initiative between the sectoral trade union in the construction industry and the employer association has led to the creation of an innovative training guide on energy efficiency, which the entire workforce will eventually benefit from.

ETUC (2011) reported with reference to the discussants of European Social Partners dialogue on Climate change that in Germany, the purpose of the "Network Resource Efficiency" is to put in place action plans to develop resource efficiency in the industrial sector (energy and raw materials) and thereby to contribute towards the greening of industry. They include the aspects linked to the needs for skills and vocational education/ training. Under this initiative, the DGB (Confederation of German Trade Unions German: Deutscher Gewerkschaftsbund) and its member organizations, in cooperation with the Environment Ministry (BMU), launched and carried out some programs to train members of works councils and employees about resource efficiency, primarily in the aluminium industry, involving the trade union organization IG Metall (Industriegewerkschaft Metall) and the German association of aluminium producers GDA.

ETUC (2011) revealed that in United Kingdom, the Government has established a high level, tripartite Green Economy Council, which has oversight of proposals for a "Green economy roadmap", a low carbon skills strategy and other low carbon initiatives. 'Union-learn', the TUC's (trade Union Congress) learning service provider, is a partner in the UK Government's project to develop a skills strategy for a low carbon, resource efficient economy. 'The role of Union-learn is to include coordinating union input in to the low carbon skills strategy; the development of Guidance for union representatives on the UKCES (UK Commission for Employment and Skills) and Sector Skills Council (SSC) Boards; work with SSCs to deliver "environmental awareness (or literacy)" provision, including the development of 'green inductions' for all employees; delivering development sessions in all 'Union learn' regions; developing modules on environmental literacy; input in to development of green careers advice; and supporting the development of locally-based greener workplace/skills initiatives with local stakeholders (employers, training colleges, local authorities, unions, NGOs and others).

ETUC (2011) further reported that for the ETUC, Green Workplace projects are union-led workplace-based initiatives that bring together the practical engagement of both workers and management to save energy and reduce the environmental footprint at work. They are characterized by awareness-raising events, surveys, training 
workshops, audits and joint consultations and initiatives. In the United Kingdom, for example, an initial set of 13 pilot projects trained 2007 environmental reps, with initiatives including $\mathrm{CO}_{2}$ (Carbon Dioxide) and resource reduction strategies. It included a TUC-led project at United Utilities which helped to join a top-down, "managerial carbon champions" initiative with a union-resourced, "bottom-up" approach focusing on mutual concerns to save energy and waste at 50 sites across the UK.

\section{Unions' Negative Role for Environment}

Unions have also been opposing the decisions and steps taken for environmental protection where their interests were in clash with these decisions, particularly American unions were not pro-environmental activities and their decisions are depicted in the quoted studies.

Kojola (2009 asserted that labor unions' support for environmental issues is often lowest during tough economic times, but green jobs is a strong positive message in the current period of stagnating wages and rising unemployment. Environmental measures are framed in terms of positive job creation and active benefits for workers. However, environmentalists still need to take steps to address union concerns, like supporting carbon reduction policies that are linked to job development and transition services, like job-training, job placement and compensation, for workers in energy-intensive industries. Kojola further elaborated that commitment to green jobs is not uniform across the labor movement, as some unions are not actively engaged in green jobs and others are still hostile to climate change and notions of environmental sustainability. AFL-CIO statements are made through consensus and thus usually represent the lowest level of agreement, so the progressive statements on climate change and green jobs are a strong indicator of fairly widespread support at the national level. Labor Unions like The United Steelworkers (USW), Communications Workers of America (CWA), International Brotherhood of Electrical Workers (IBEW), SEIU, and (The Laborers' International Union of North America - USA) LIUNA have started thinking innovatively about green jobs and the relationship between social justice, economics and environmental sustainability. However, other unions, like the UMW and the Building Trades have been more hesitant and slow to take action. Unions with membership who stand to gain directly from a green economy are likely to be supportive. The Communications Workers of America (CWA) and USW have members in a wide range of occupations, including large numbers in manufacturing who would benefit from producing clean energy technologies, like wind turbines and solar PV panels. IBEW and LIUNA members will also be engaged in much of the direct work of building a new energy infrastructure and improving efficiency. However, unions like the United Mine Workers (UMW) see less potential benefit because their membership is concentrated in a fossil fuel based industry and have a legitimate fear of job loss from dramatic decreases in coal use. Still, the UMW is showing signs of new thinking, like signing on to a report by the Center on Globalization, Governance and Competitiveness about carbon-reducing technologies and jobs.

\section{Conclusion}

No doubt Snell et al. (n.d) concluded trade unions are rarely recognized for their roles and activities outside of industrial matters and when union activities surrounding non-industrial matters they are often analyzed in relation to productive relations and the vested interests of trade union organizations.

But from the study of literature quoted above it can be asserted that labor unions as a whole have been enthusiastic activist in pro environmental activities and they put their due share for protection of environment by providing awareness to their members about environmental issues, and also by providing training and education of equipment and technology and methods to avoid deterioration of environment. Discussants of CSD (2008) were right by saying that worker and trade union involvement are essential ingredients for change where collaboration with employers and governments could facilitate effective workplace action for environmental protection and community well being. As unions can make direct demands on employers, pressure the government on environmental issues and build coalitions (Kojola 2009) so it is expected in the words of Kojola that the role of unions will be an essential factor in determining the direction of a future green economy and the possibility for creating an equitable economy and protecting workers. Governments and Environment protection agencies should make the best use of unions' cooperation and enthusiasm for environmental protection by involving them in their campaigns and decisions. 


\section{References}

Buffa, A.; Carol Z.; Cheryl B. and Dave G.S. (2008) "California's Global Warming Solutions Act of 2006", A Background Paper for Labor Unions, Workforce and Economic Development, A Program of California Labor Federation, AFL-CIO

Canadian Labor Congress (2003) Canadian Labor Congress: Green Job Creation Project, Background Paper, adopted 2003

CSD (2008) "A Trade Union Review on Agriculture, Rural Development, Desertification, Drought, Land \& Africa", 16th Commission on Sustainable Development, New York, 5-16 May 2008

ETUC (2002) "European Trade Unions Actors for Sustainable Development", European Trade Union Technical Bureau for Health and Safety, contribution to the Johannesburg Earth Summit 2002 ISBN: 2-930003-42-1, D/2002/6107/43, www.etuc.org/tutb/uk/sustainable-development.html:

ETUC (2011) "European Social Partners dialogue on Climate change 13 May 2011", European Trade Union Confederation Discussion Document

European Foundation (2011) "Industrial relations and sustainability: The role of social partners in the transition towards a green economy", European Foundation for the Improvement of Living and Working Conditions, Résumé, http://www.eurofound.europa.eu

Evans, John (2009) "Changing the paradigm: greener and fairer" Green Growth For Jobs and Social Justice, Getting the World to Work, December 2009, Published by Global Union Movement

Gabaglio, E. G.; Sapir, M. (2002) "European Trade Unions Actors for SustainableDevelopment", An ETUC contribution to the Johannesburg Earth Summit 2002, Actors for Sustainable Development, European Trade Union Technical Bureau for Health and Safety, ISBN: 2-930003-42-1, D/2002/6107/43

Ghayur, S. (1996) Labor Issues in Pakistan" Pakistan Institute of Labor education and Research Karachi- PAKISTAN

ILO, "World Labour Report 1997-98, Industrial relations, democracy and social stability" Social Dialogue, Labour Law and Labour Administration Department (DIALOGUE),

Inoue, Sadahiko (1999) "Japanese Trade Unions and Their Future: Opportunities and challenges in an era of globalization, Discussion papers, DP/106/1999, Labor and Society Program, Rengo Institute for Advancement of Living Standards, Tokyo, Japan

Khan, Muhammad Tariq (2008) Social Role of Labor Unions, Science Vision （COMSATS) Vol. 14, Issue 1, 2008:79-93

Khan Dr. Muhammad Tariq (2010) "Role of Labor Unions Beyond Collective", Far East Journal of Psychology and Business, Vol. 1 No 1, December 2010: 78-90

Khan, Dr. M. T. and Khan, Dr. N. A. (2011) "Role of Labor Unions Beneficial for Employer", Far East Journal of Psychology and Business, Vol. 4 No 3, (September 2011): 56-71

Knowles, Caroline and Eade, Deborah (n.d.) "Labor Unions and Development: An Annotated List of Selected Resources" Retrieved, May 23, from http://www.developmentinpractice.org/readers/Labor\%20Unions/Labor\%20Unions\%20Resources.pdf

Kojola, Erik (2009) "Trade Unions and Green Jobs in the post-Fordist Economy: Just Rhetoric or a Fundamental Shift?" BA, Oberlin College Honors Theses, Politics, 2009. Document number: oberlin 241906474 http://etd.ohiolink.edu/view.cgi?acc_num=oberlin1241906474

Leeuwen, F (2009) "Learning to adapt", Green Growth For Jobs and Social Justice, Getting the World to Work December 09 Published by Global Union Movement

Oswald, Ron and Eldret, Lisa (2009) "Cleaning up travel and tourism" Green Growth For Jobs and Social Justice, Getting the World to Work, December 2009, Published by Global Union Movement

Ryder, Guy (2009) "Working for a Just Transition" Green Growth For Jobs and Social Justice, Getting the World to Work, December 2009, Published by Global Union Movement

Snell, D.; Fairbrother, P. and Hart A. (n.d) "Blue-Green Alliances: union capacities and prospects as environmental actors", Global Work and Employment Research Group, School of Management Royal Melbourne Institute of Technology (RMIT) University Melbourne, Victoria Australia

Valenduc, Gérard (2000) "Trade unions as agents of environmental awareness: outcomes from the RISE project" Eckhart Hildebrandt, Borge Lorentzen, Eberhard Schmidt (Eds.) Towards a Sustainable Worklife Hans Böckler Stiftung - Edition Sigma, Berlin, 2001: 55-66

White, Aidan (2009) "Setting standards for the climate" Green Growth For Jobs and Social Justice, Getting the World to Work, December 2009, Published by Global Union Movement

WSSD (2002) "World Summit on Sustainable Development" Economic and Social Council, UNITED NATIONS- First Substantive Session 28 January - 8 February 2002, Retrieved August, 30, 2005 from http://www.johannesburgsummit.org/html/major_groups/workerstradeunionfinal.doc 